$\begin{gathered}\text { ADVANCE RESEARCH JOURNAL OF SOCIAL SCIENCE } \\ \begin{array}{c}\text { ReSEARCH } \\ \text { Note }\end{array}\end{gathered}$
$\begin{gathered}\text { volume } 7 \mid \text { Issue } 2 \mid \text { December, } 2016 \mid 284-285 \\ \text { e ISSN-2231-6418 }\end{gathered}$
DOI: 10.15740/HAS/ARJSS/7.2/284-285

\title{
Prevention of post harvest loss of bell by Badi preparation
}

P.L. Shrivastava

Krishi Vigyan Kendra, BALLIA (U.P.) INDIA

(Email: dr.premlata99@gmail.com)

\section{ARTICLE INFO :}

Received : 03.08 .2016

Accepted : 30.11 .2016

\section{KEY WORDS :}

Women education, Technical training, Adequate extension facilities, Bell bari

HOW TO CITE THIS ARTICLE :

Shrivastava, P.L. (2016). Prevention of post harvest loss of bell by Badi preparation. Adv. Res. J. Soc. Sci., 7 (2) : 284-285, DOI: 10.15740/HAS/ARJSS/ 7.2/284-285.

\section{ABSTRACT}

A survey based study was carried out from the year 2015 to 2016 in the rural Ballia of Uttar Pradesh to know the post harvest loss of bell, method of prevention used in rural areas to stop the spoilage and acceptance of bell bari as a means to prevent post harvest loss of bell. A personal interview schedule developed was used. Fifty male and female respondent were interviewed. Fifty per cent spoilage was observed in case of bell and no any method to prevent the spoilage. KVK analyzed the problem critically and found the solution in the form of preservation, value addition and other transformation by way of training and demonstration. Looking production, low consumption during peak period and post harvest loss of bell KVK formulated preparation of bell bari. Acceptability of bari as a was tested by man and women. Hundred per cent showed their fully acceptance. Women education, technical training and adequate extension facilities can create a positive impact leading to a better tomorrow. 